\title{
Modeling: ratio between means of teaching and motor training in junior school physical education classes
}

Olha Ivashchenko ${ }^{1 \mathrm{ABCDE}}$, Sergii Iermakov ${ }^{2 \mathrm{ABCDE}}$, Oleg Khudolii1 ${ }^{1 \mathrm{ABCDE}}$

${ }^{1}$ H. S. Skovoroda Kharkiv National Pedagogical University, Ukraine

${ }^{2}$ Gdansk University of Physical Education and Sport, Poland

Authors' Contribution: A - Study design; B - Data collection; C - Statistical analysis; D - Manuscript Preparation; E - Funds Collection

\begin{abstract}
Background The purpose of the study was to determine the ratio between means of teaching and motor training in and Study Aim junior school physical education classes.

Material and The study involved 32 boys who were 8 years old at the beginning of the experiment. They were randomly Methods divided into four groups of eight people each. A pedagogical experiment was conducted using a $2^{2}$ full factorial design. The study recorded the following indicators: number of repetitions required to teach exercises; grade for a unidirectional movement coordination exercise (test 1); grade for a multidirectional movement coordination exercise (test 2); error in time accuracy of performing the squat thrust (test 3); error in time accuracy of 5 jumps on marks in $5 \mathrm{~s}$ (test 4); error in assessing muscular effort with visual control (test 5); vestibular stability, error (test 6). The obtained experimental material was processed statistically using statistical analysis software packages (SPSS 20).

Results According to the logistic function analysis, the achievement of an optimal result in differentiating temporal characteristics of movement requires 8.5 months, strength characteristics of movement -8 months, movement coordination - 8 months, vestibular analyzer stability - 10 months. It takes 3 to 5 months to obtain positive increases in testing results in boys aged 8-9. The ratio of time allotted for strength training (ST) and coordination training (CT) to teaching motor actions (TMA) varies as 1:4 (ST: TMA) and 1:4.5 (CT: TMA).

Conclusions: The ratio of time allotted for strength training, coordination training, and teaching to the time of the main part of the class ranges between 14.3-23.5\% (strength training), 17.1-23.5\% (coordination training), and $53.0-68.6 \%$ (teaching). As exercises become more complicated, the time allotted for strength and coordination training increases.

Keywords: $\quad$ boys aged 8-9, logistic function, strength training, coordination training, teaching.
\end{abstract}

\section{Introduction}

In modern school, the physical education class is viewed as the main form of schoolchildren's motor activity [1-3]. The class aims to develop motor skills and motor abilities [4-6]. The process of teaching and motor abilities development in children and adolescents was studied in the following areas:

- motor training methodology [7-9];

- motor skills in the structure of schoolchildren's physical fitness [1, 10-12];

- gender-related peculiarities of motor skills development [13]; 16];

-factors influencing motor skills development [14-

- pedagogical control in the process of motor skills development [17-19];

- influence of motor skills development on improving the health of children and adolescents [20, 21].

It was found that the effectiveness of motor skills development is influenced both by the mode of exercises [22-24] and the content of teaching [25-27].

Studies of motor skills development used a factorial experiment to examine the structure of the educational process [28, 29], modeling [30, 31], the logistic function (c) Olha Ivashchenko, Sergii lermakov, Oleg Khudolii, 2021 doi:10.15561/26649837.2021.0308 analysis to determine the duration of training and motor abilities development in children and adolescents [30, 31]. Researchers established the effectiveness of using the modeling method to obtain new information about the patterns of motor skills development.

However, there are few studies aimed at investigating the ratio between means of teaching and motor training in junior school physical education classes. Most studies focus on the structure of motor fitness $[1,10]$, modes of exercises during training [28].

Thus, the problem of determining the ratio between means of teaching and motor training in junior school physical education classes is relevant and requires further research.

The purpose of the study was to determine the ratio between means of teaching and motor training in junior school physical education classes.

\section{Materials and methods}

Participants

The study involved 32 boys who were 8 years old at the beginning of the experiment. They were randomly divided into four groups of eight people each. The children and their parents were informed about all the features of the study and gave their consent to participate 
in the experiment.

Research Design

A pedagogical experiment was conducted using a $2^{2}$ full factorial design (Table 1). Strength and coordination training was carried out by means of basic gymnastics. The boys were taught the forward roll and the straddle vault over side vaulting buck. The study recorded the level of proficiency in the exercises $p=m / n$, where $m$ is the number of successful attempts, $\mathrm{n}$ is the total number of attempts. For strength development, the combined method according to the first variant was used. Exercises at one place are performed in the following order: dynamic effort method, maximal effort method, isometric effort method, repeated effort method. For movement coordination development - repeated method, in the process of teaching - method of algorithmic instructions.

The study recorded the following indicators: number of repetitions required to teach exercises; grade for a unidirectional movement coordination exercise (test 1 ); grade for a multidirectional movement coordination exercise (test 2); error in time accuracy of performing the squat thrust (test 3); error in time accuracy of 5 jumps on marks in $5 \mathrm{~s}$ (test 4); error in assessing muscular effort with visual control (test 5); vestibular stability, error (test 6).

\section{Testing methods}

Test 1. Grade for a unidirectional movement coordination exercise, points.

Starting position (s.p.) - normal standing position (n.s.p.), 1 - step with the left leg, hands forward; 2. - s.p.; 3 - step with the right leg, hands up; 4 - s.p.

Test 2. Grade for a multidirectional movement coordination exercise, points.

S.p. - n.s.p. 1 - step with the left leg, right hand forward; 2 - s.p.; 3 - step with the right leg, hands up; 4 - s.p.

The tests were evaluated on the following scale: 10 points - mistake-free performance of the test; 9.5 points one mistake was made (no coordination between arm and leg movements, one of the movements was forgotten); 9 points - two mistakes were made; 8.5 points - three mistakes were made.

General instructions and remarks. The teacher shows and performs the test once according to distribution, after which the students perform the test to the count for a grade.

Test 3. Error in time accuracy of performing the squat thrust 3 times in $3 \mathrm{~s}$.

Test procedure. The test participant assumes the squat position. At the "Go" command, the participant begins to rhythmically perform the exercise.

Result. Time of performing the exercise. The error in time accuracy of performing the exercise is analyzed.

Test 4. Error in time accuracy of 5 jumps on marks in $5 \mathrm{~s}$.

Test procedure. At the "Go" command, the test participant performs 5 jumps on marks, the distance between the marks is $50 \mathrm{~cm}$.

Result. Time of performing the exercise. The error in time accuracy of performing the exercise is analyzed.

Test 5. Standing long jump at half strength, error in $\%$.

This test was performed to assess muscular effort with visual control.

Equipment. Non-slip surface with a line and marking in centimeters.

Test procedure. The test participant toes the line, with a two foot take-off and arm swing jumps as far forward as possible, then repeats the jump at half strength.

Result. The distance of the maximum-effort jump and the distance of the jump at half strength were recorded in centimeters. The error in \% was analyzed.

General instructions and remarks. The test is carried out in accordance with the rules for standing long jump competitions. Take-off and landing places must be at the same level.

Test 6 . Walking in a straight line after three $360^{\circ}$ turns, error $\mathrm{cm}$

This test was performed to assess vestibular stability.

Test procedure. After three turns of $360^{\circ}$ each, stand with the back against the wall and walk $4 \mathrm{~m}$ in a straight line.

Result. Deviation from a straight line in centimeters.

Statistical analysis

To analyze the results, the algorithm from the studies by Khudolii et al. [29], Lopatiev et al. [30], Khudolii [31] was used.

1. The analysis of change in the results of strength and coordination fitness in the groups of factorial design showed that this process can be described using growth models:

Table 1. Matrix of the $2^{2}$ factorial experiment in studying the influence of ratio variants of training means in the class on the level of strength, coordination fitness and proficiency in motor actions in boys aged 8-9 years

\begin{tabular}{llllll}
\hline Group & $\mathbf{N}$ & $\begin{array}{l}\text { Ratio variant of } \\
\text { training means } \\
\text { in the class }\end{array}$ & $\begin{array}{l}\text { Strength } \\
\text { training, } \mathbf{m i n} .\end{array}$ & $\begin{array}{l}\text { Coordination training, } \\
\text { min. } \\
\mathbf{X}_{1}\end{array}$ & $\begin{array}{l}\mathbf{X}_{2} \\
\text { Teaching motor } \\
\text { actions, min. }\end{array}$ \\
\hline Group 1 & 8 & 1 & 0 & 0 & 33 \\
Group 2 & 8 & 2 & 12 & 0 & 21 \\
Group 3 & 8 & 3 & 0 & 9 & 24 \\
Group 4 & 8 & 4 & 12 & 9 & 12 \\
\hline
\end{tabular}




$$
\mathrm{Y}=\mathrm{A} /\left(1+10^{\left(\mathrm{a}_{\mathrm{m}}+\mathrm{bx}\right)}\right)+\mathrm{C}
$$

where $\mathrm{Y}$ is the effectiveness of teaching motor actions, $\mathrm{X}$ is the number of training sessions held since the beginning of teaching the motor action, $\mathrm{A}$ is the distance between the upper $(\mathrm{A}-\mathrm{C})$ and lower $(\mathrm{C})$ asymptotes, $\mathrm{C}$ is the lower asymptote, the point where the training begins; $\mathrm{a}, \mathrm{b}$ are the parameters that determine the slope, bending, and inflection point of the logistic regression line.

2 . The regression equation coefficients of the logistic function vary depending on the mode of training. Their change can be described by the following equation:

$$
\mathrm{Y}=\mathrm{b}_{0}+\mathrm{b}_{1} \mathrm{x}_{1}+\mathrm{b}_{2} \mathrm{x}_{2}+\mathrm{b}_{3} \mathrm{x}_{1} \mathrm{x}_{2} \text {, }
$$

where $Y$ is the effectiveness of training process; $x_{1}$ is the time allotted for strength training; $\mathrm{x}_{2}$ - for coordination training.

3. The following formulas were used to determine an optimal result and time of its achievement:

$$
\begin{gathered}
\text { Yopt. } 1=\text { Yo }+0.632 \times(\mathrm{A}+\mathrm{C}-\text { Yo }) \\
\text { Zopt.up }=0.117 \times(\mathrm{A}+\mathrm{C}-\text { Yo }) \\
\text { Ymax }=\text { Yopt. } 1+0.632 \times \text { Zopt.up }
\end{gathered}
$$

where Yopt.1 is top optimum, Zopt.up is the zone of top optimum, Yo is the function's value at the point of inflection $(\mathrm{am} / \mathrm{b})$.

$$
\begin{gathered}
\text { Yopt. } 2=\text { Yo }+0.368 \times(\text { Yo-C }) \\
\text { Zopt.down }=0.117 \times(\text { Yo-C }) \\
\text { Ymin }=\text { Yopt.2-0.368 } \times \text { Zopt.down } \\
\mathrm{Xmax}=(\lg (\mathrm{A} /(\text { Ymax-C })-1)-\mathrm{am}) / \mathrm{b} \\
\mathrm{Xmin}=(\lg (\mathrm{A} /(\text { Ymin-C) }-1)-\mathrm{am}) / \mathrm{b}
\end{gathered}
$$

where Xmax and Xmin are values of the argument at the points where the function takes MINMAX.

4. To determine the similarity between experimental and theoretical points, analysis of variance was performed.
Correlation coefficient, Fisher criterion were calculated.

5. Computational experiment. To determine an optimal ratio of time allotted for strength and coordination training, a computational experiment was conducted. Its essence is to create an array of data on 120 training modes and analyze the two-dimensional distribution. The computational experiment was conducted in two stages:

1. Based on the regression equations: $Y=b_{0}+b_{1} x_{1}$ $+b_{2} x_{2}+b_{3} x_{1} x_{2}$, where $x_{1}$ is the time allotted for strength training; $x_{2}$ - for coordination training, an array of data was created $Y[i, j]$, where $i$ is the counter of variants of training modes, $j$ is the counter of analyzed parameters (increase in the result, time of achieving the result, time for strength, coordination training, technical training).

2. Analysis of the two-dimensional distribution of an increase in the result, time of achieving an optimal result, time for strength, coordination training, and teaching movements.

The obtained experimental material was processed statistically using statistical analysis software packages (SPSS 20).

The study protocol was approved by the Ethical Committee of the University. In addition, the children and their parents or legal guardians were fully informed

\begin{tabular}{|c|c|c|c|c|c|c|c|c|c|c|c|c|c|}
\hline \multirow{2}{*}{$\mathbf{N}$} & \multirow{2}{*}{ Test } & \multicolumn{3}{|c|}{ Group 1} & \multicolumn{3}{|c|}{ Group 2} & \multicolumn{3}{|c|}{ Group 3} & \multicolumn{3}{|c|}{ Group 4} \\
\hline & & $\mathbf{R}$ & $\mathbf{F}$ & $\mathbf{p}$ & $\mathbf{R}$ & $\mathbf{F}$ & p & $\mathbf{R}$ & $\mathbf{F}$ & $\mathbf{p}$ & $\mathbf{R}$ & $\mathbf{F}$ & $\mathbf{p}$ \\
\hline 1. & $\begin{array}{l}\text { Grade for a unidirectional } \\
\text { movement coordination } \\
\text { exercise, points }\end{array}$ & 0.937 & 0.003 & $<0.05$ & 0.896 & 0.526 & $<0.05$ & 0.838 & 0.051 & $<0.05$ & 0.998 & 0.163 & $<0.05$ \\
\hline 2. & $\begin{array}{l}\text { Grade for a } \\
\text { multidirectional } \\
\text { movement coordination } \\
\text { exercise, points }\end{array}$ & 0.489 & 0.272 & $<0.05$ & 0.879 & 0.608 & $<0.05$ & 0.980 & 0.087 & $<0.01$ & 0.771 & 0.845 & $<0.05$ \\
\hline 3. & $\begin{array}{l}\text { Error in time accuracy } \\
\text { of performing the squat } \\
\text { thrust }\end{array}$ & 0.586 & 1.065 & $<0.05$ & 0.936 & 0.399 & $<0.05$ & 0.944 & 1.107 & $<0.05$ & 0.512 & 0.568 & $<0.05$ \\
\hline 4. & $\begin{array}{l}\text { Error in time accuracy of } 5 \\
\text { jumps on marks in } 5 \mathrm{~s}\end{array}$ & 0.482 & 0.854 & $<0.05$ & 0.734 & 0.437 & $<0.05$ & 0.925 & 0.454 & $<0.05$ & 0.320 & 1.124 & $<0.05$ \\
\hline 5. & $\begin{array}{l}\text { Error in assessing } \\
\text { muscular effort with visual } \\
\text { control }\end{array}$ & 0.613 & 0.767 & $<0.05$ & 0.526 & 0.049 & $<0.05$ & 0.911 & 0.245 & $<0.05$ & 0.708 & 1.189 & $<0.05$ \\
\hline 6. & $\begin{array}{l}\text { Vestibular stability, error } \\
\mathrm{cm}\end{array}$ & 0.874 & 0.002 & $<0.05$ & 0.111 & 0.311 & $<0.05$ & 0.964 & 0.112 & $<0.05$ & 0.876 & 0.388 & $<0.05$ \\
\hline
\end{tabular}
about all the features of the study, and a signed informedconsent document was obtained from all the parents.

\section{Results}

The analysis of the study results is given in Tables 2-6. Math analysis of the logistic function made it possible to conclude about a similarity between experimental and theoretical points (Table 2).

Table 2. Results of the analysis of similarity between experimental and theoretical points calculated using the logistic function equation. 
The change in the ability to coordinate unidirectional and multidirectional movements is most influenced by variants of training 1 and 4 . The boys of group 4 achieve a maximum result in 7.5 months, and the boys of group 1 - in 15 months (Table 3).

The change in the error in differentiating temporal characteristics of movement is positively influenced by variants of training 1, 3 and 4. Group 3, where maximum attention was paid to coordination training, shows the greatest speed in achieving a maximum result (Table 3 ).

The boys of group 3 show a higher result in less training time in differentiating muscular effort and in vestibular stability. It is noteworthy that achieving a similar result when using only the means of technical training takes twice as much time (Table 3).

According to the logistic function analysis, the achievement of an optimal result in differentiating temporal characteristics of movement requires 8.5 months, strength characteristics of movement -8 months, movement coordination -8 months, vestibular analyzer stability - 10 months. Thus, when planning physical education lessons during the $2^{\text {nd }}$ and $3^{\text {rd }}$ grades of training, it is necessary to allocate time for strength, coordination training, and teaching movements. The main means of developing motor abilities is basic gymnastics.

The analysis of the computational experiment showed that the increases in the results are normally distributed with a certain degree of assumption, and the arithmetic mean and the root mean square are the most important characteristics of the sample. The optimal step of increase is a value equal to $M \pm s$, because the probability of achieving this result is the highest (Table 4).

Table 5 shows the ratio between the means of strength, coordination training and teaching in the class of boys aged 8-9 years.

It takes 3 to 5 months to obtain positive increases in testing results in boys aged 8-9. The ratio of time allotted for strength training (ST) and coordination training (CT) to teaching motor actions (TMA) varies as 1:4 (ST: TMA) and 1:4.5 (CT: TMA).

The process of teaching the most difficult movements for this age was similarly analyzed. Based on the computational experiment, it was determined that the results of training are normally distributed, and the arithmetic mean and the root mean square are the most important characteristics of the sample (Table 6).

Table 7 shows the ratio between the means of strength and coordination training when teaching movements to boys aged 8-9 years. It is noteworthy that as exercises become more complicated, the time allotted for strength and coordination training increases, but these indicators do not reach maximum values adopted in the experiment. The ratio of time allotted for strength training, coordination training, and teaching to the time of the main part of the class ranges between 14.3-23.5\% (strength training), $17.1-23.5 \%$ (coordination training), and 53.0-68.6\% (teaching).

Table 3. Results of the logistic function analysis. Optimal result $(\mathrm{Y})$ and time of its achievement (t, months)

\begin{tabular}{|c|c|c|c|c|c|c|c|c|c|}
\hline \multirow{2}{*}{ No } & \multirow{2}{*}{ Test } & \multicolumn{2}{|c|}{ Group 1} & \multicolumn{2}{|c|}{ Group 2} & \multicolumn{2}{|c|}{ Group 3} & \multicolumn{2}{|c|}{ Group 4} \\
\hline & & $\mathbf{Y}$ & $t$ & $\mathbf{Y}$ & $t$ & $\mathbf{Y}$ & $t$ & $\mathbf{Y}$ & $t$ \\
\hline 1. & $\begin{array}{l}\text { Grade for a } \\
\text { unidirectional } \\
\text { movement } \\
\text { coordination exercise, } \\
\text { points }\end{array}$ & 9.59 & 15.34 & 8.447 & 7.74 & 8.835 & 15.26 & 9.419 & 7.57 \\
\hline 2. & $\begin{array}{l}\text { Grade for a } \\
\text { multidirectional } \\
\text { movement } \\
\text { coordination exercise, } \\
\text { points }\end{array}$ & 9.49 & 27.72 & 8.788 & 8.70 & 7.596 & 9.02 & 9.347 & 7.81 \\
\hline 3. & $\begin{array}{l}\text { Error in time accuracy } \\
\text { of performing the } \\
\text { squat thrust }\end{array}$ & 0.26 & 13.29 & 0.286 & 0.18 & 0.225 & 12.62 & 0.302 & 17.17 \\
\hline 4. & $\begin{array}{l}\text { Error in time accuracy } \\
\text { of } 5 \text { jumps on marks } \\
\text { in } 5 \mathrm{~s}\end{array}$ & 0.35 & 27.50 & 0.351 & 10.86 & 0.394 & 8.51 & 0.392 & 26.04 \\
\hline 5. & $\begin{array}{l}\text { Error in assessing } \\
\text { muscular effort with } \\
\text { visual control, \% }\end{array}$ & 14.73 & 4.62 & 8.590 & 26.65 & 7.470 & 10.04 & 9.475 & 12.66 \\
\hline 6. & $\begin{array}{l}\text { Vestibular stability, } \\
\text { error } \mathrm{cm}\end{array}$ & 6.56 & 19.26 & 5.739 & 19.0 & 5.975 & 9.82 & 8.174 & 7.06 \\
\hline
\end{tabular}


Table 4. Computational experiment results. Elementary statistics

\begin{tabular}{|c|c|c|c|c|c|c|c|c|}
\hline No & Test & $\mathbf{x}$ & s & As & Ex & $\lambda$ & $x_{2}$ & $\mathbf{N}$ \\
\hline 1. & $\begin{array}{l}\text { Grade for a unidirectional } \\
\text { movement coordination } \\
\text { exercise, points }\end{array}$ & 1.878 & 1.117 & -0.163 & -0.709 & 1.442 & 74.762 & 120 \\
\hline 2. & $\begin{array}{l}\text { Grade for a multidirectional } \\
\text { movement coordination } \\
\text { exercise, points }\end{array}$ & 2.628 & 1.466 & -0.192 & -0.738 & 1.558 & 147.638 & 120 \\
\hline 3. & $\begin{array}{l}\text { Error in time accuracy of } \\
\text { performing the squat thrust }\end{array}$ & -0.254 & 0.238 & -13.232 & -1.315 & 1.130 & 69.453 & 120 \\
\hline 4. & $\begin{array}{l}\text { Error in time accuracy of } 5 \\
\text { jumps on marks in } 5 \mathrm{~s}\end{array}$ & -0.268 & 0.151 & 194.021 & -0.819 & 1.963 & 125.195 & 120 \\
\hline 5. & $\begin{array}{l}\text { Error in assessing muscular } \\
\text { effort with visual control }\end{array}$ & -1.848 & 2.740 & 0.001 & -1.067 & 1.154 & 39.674 & 120 \\
\hline 6. & Vestibular stability, error $\mathrm{cm}$ & -1.119 & 0.740 & 0.222 & -1.004 & 0.956 & 63.750 & 120 \\
\hline
\end{tabular}

Table 5. Ratio between the means of strength and coordination training in the physical education class of boys aged 8-9 years

\begin{tabular}{|c|c|c|c|c|c|c|c|c|c|c|}
\hline \multirow[t]{2}{*}{ No } & \multirow[t]{2}{*}{ Test } & \multirow[t]{2}{*}{$\begin{array}{l}\text { Increase } \\
\text { in the } \\
\text { result }\end{array}$} & \multicolumn{2}{|c|}{$\begin{array}{l}\text { Time of } \\
\text { achieving } \\
\text { the result } \\
\text { (months) }\end{array}$} & \multicolumn{2}{|c|}{$\begin{array}{l}\text { Strength } \\
\text { training } \\
\text { (min) }\end{array}$} & \multicolumn{2}{|c|}{$\begin{array}{l}\text { Coordination } \\
\text { training } \\
\text { (min) }\end{array}$} & \multicolumn{2}{|c|}{$\begin{array}{l}\text { Teaching } \\
\text { motor } \\
\text { actions (min) }\end{array}$} \\
\hline & & & $\mathbf{Y}$ & $\mathbf{s}$ & $\mathbf{Y}$ & $\mathbf{s}$ & $\mathbf{Y}$ & $\mathbf{s}$ & $\mathbf{Y}$ & $\mathbf{s}$ \\
\hline 1. & $\begin{array}{l}\text { Grade for a unidirectional } \\
\text { movement coordination exercise, } \\
\text { points }\end{array}$ & 2.814 & 3.021 & 0.386 & 8.41 & 2.27 & 3.692 & 2.25 & 22.897 & 4.452 \\
\hline 2. & $\begin{array}{l}\text { Grade for a multidirectional } \\
\text { movement coordination exercise, } \\
\text { points }\end{array}$ & 4.025 & 3.092 & 0.155 & 4.533 & 2.51 & 5.933 & 1.58 & 24.533 & 3.966 \\
\hline 3. & $\begin{array}{l}\text { Error in time accuracy of performing } \\
\text { the squat thrust }\end{array}$ & -0.432 & 5.031 & 0.189 & 4.111 & 1.328 & 5.083 & 3.088 & 25.806 & 4.336 \\
\hline 4. & $\begin{array}{l}\text { Error in time accuracy of } 5 \text { jumps on } \\
\text { marks in } 5 \mathrm{~s}\end{array}$ & -0.396 & 4.601 & 0.817 & 4.974 & 3.03 & 3.385 & 2.451 & 26.641 & 2.144 \\
\hline 5. & $\begin{array}{l}\text { Error in assessing muscular effort } \\
\text { with visual control }\end{array}$ & -4.478 & 4.597 & 0.663 & 7.238 & 2.437 & 6.214 & 2.19 & 21.548 & 0.791 \\
\hline 6. & Vestibular stability, error $\mathrm{cm}$ & -1.844 & 3.136 & 0.544 & 5.524 & 3.384 & 7.143 & 1.406 & 22.333 & 1.399 \\
\hline
\end{tabular}

Table 6. Computational experiment results. Elementary statistics. Boys aged 8-9 years

\begin{tabular}{llllllll}
\hline Exercise & $\mathbf{X}$ & $\mathbf{S}$ & As & Ex & $\boldsymbol{\lambda}$ & $\boldsymbol{X}_{\mathbf{2}}$ & $\mathbf{N}$ \\
\hline Forward roll, $(p=\mathrm{m} / \mathrm{n})$ & 0.895 & 0.064 & -8.490 & 1.126 & 1.403 & 18.831 & 100 \\
$\begin{array}{l}\text { Straddle vault over side vaulting buck } \\
(\mathrm{p}=\mathrm{m} / \mathrm{n})\end{array}$ & 0.630 & 0.104 & -7.436 & -0.619 & 0.480 & 5.716 & 100 \\
\hline
\end{tabular}


Table 7. Ratio between the means of strength and coordination training according to the indicators of teaching movements to boys aged 8-9 years

\begin{tabular}{|c|c|c|c|c|c|c|c|}
\hline \multirow{2}{*}{ Exercise } & \multirow{2}{*}{ Result } & \multicolumn{2}{|c|}{$\begin{array}{l}\text { Strength training } \\
(\min )\end{array}$} & \multicolumn{2}{|c|}{$\begin{array}{l}\text { Coordination } \\
\text { training (min) }\end{array}$} & \multicolumn{2}{|c|}{$\begin{array}{l}\text { Teaching motor } \\
\text { actions (min) }\end{array}$} \\
\hline & & $\mathbf{Y}$ & $\mathbf{s}$ & $Y$ & $\mathbf{s}$ & $\mathbf{Y}$ & $\mathbf{s}$ \\
\hline Forward roll, $(p=m / n)$ & 1. 0.936 & 5 & 1.885 & 6.071 & 2.01 & 23.929 & 5.744 \\
\hline $\begin{array}{l}\text { Straddle vault over side vaulting buck, } \\
(p=m / n)\end{array}$ & 2. 0.735 & 8.25 & 2.5 & 8.063 & 1.611 & 18.687 & 2.324 \\
\hline
\end{tabular}

\section{Discussion}

An assumption was made about the possibility of using factorial designs and analysis of the logistic function to assess the effectiveness of different structures of physical education classes in junior school. The study established the effectiveness of the algorithm of computer modeling of the structure of physical education classes.

During the analysis, the study determined the structure of the main part of the class, which ensures the effectiveness of motor abilities and motor skills development.

The obtained data supplement the information on the factors that influence the effectiveness of motor skills development [14-16]; on the technique of pedagogical control in the process of motor skills development [1719]; confirm the information that the conditions for motor skills development are one of the factors that determine the effectiveness of teaching schoolchildren [1, 10-12].

In addition, the study supplements the data on the effectiveness of using factorial designs in studying the patterns of motor skills development [28, 29]. Also, the results of the study confirm the effectiveness of using the logistic function to determine the duration of training and motor abilities development in children and adolescents $[30,31]$.

The results of the study can be used to plan strength and coordination training, and teaching basic gymnastics exercises in junior school physical education classes. The data given in Tables 5 and 7 are recommended for planning. The main method of strength development is the combined method according to the first variant. Exercises at one place are performed in the following order: dynamic effort method, maximal effort method, isometric effort method, repeated effort method. The development of strength and movement coordination is seen as a condition for successful motor skills development.

\section{Conclusions}

The logistic function analysis showed that the achievement of an optimal result in differentiating temporal characteristics of movement requires 8.5 months, strength characteristics of movement and movement coordination -8 months, vestibular analyzer stability 10 months. When planning physical education lessons during the $2^{\text {nd }}$ and $3^{\text {rd }}$ grades of training, it is necessary to allocate time for strength, coordination training, and teaching movements. The main means of developing motor abilities is basic gymnastics.

The ratio of time allotted for strength, coordination training, and teaching to the main part of the class ranges between 14.3-23.5\% (strength training), 17.1-23.5\% (coordination training), and 53.0-68.6\% (teaching). As exercises become more complicated, the time allotted for strength and coordination training increases.

\section{Acknowledgement}

The study was carried out in accordance with the plan of research work of the Department of Theory and Methodology of Physical Education of H. S. Skovoroda Kharkiv National Pedagogical University.

\section{Conflict of interest}

The authors declare no conflict of interest.

\section{References}

1. Petrov D, Khudolii O, Cieślicka M. Motor Skills: Motor Fitness Structure of 9-Year-Old Boys. Journal of Learning Theory and Methodology, 2020; 1(2): 58-63. https://doi.org/10.17309/j1tm.2020.2.02

2. Agosti V, Madonna G. From movement to action: New perspectives in motor learning and sport training. Sport Science, 2020; 14: 40-43.

3. Bjørke L, Mordal Moen K. Cooperative learning in physical education:Astudy of students'learning journey over 24lessons. PhysicalEducationandSportPedagogy, 2020;25(6):600-612. https://doi.org/10.1080/17408989.2020.1761955

4. Bores-García D, Hortigüela-Alcalá D, FernandezRio FJ, González-Calvo G, Barba-Martín R. Research on Cooperative Learning in Physical Education: Systematic Review of the Last Five Years. Research Quarterly for Exercise and Sport, 2021; 92(1): 146-155. https://doi.org/10.1080/02701367.2020.1719276

5. Capella-Peris C, Gil-Gómez J, Chiva-Bartoll Ò. Innovative analysis of service-learning effects in physical education: A mixed-methods approach. Journal of Teaching in Physical Education, 2020; 39(1): 102-110. https://doi.org/10.1123/jtpe.2019-0030

6. Coimbra M, Cody R, Kreppke J-N, Gerber M. Impact of a physical education-based behavioural skill training program on cognitive antecedents and exercise and sport behaviour among adolescents: A cluster-randomized controlled trial. Physical Education and Sport Pedagogy, 2021; 26(1): 16-35. 
https://doi.org/10.1080/17408989.2020.1799966

7. Gaetano R. Motor learning and didactics into physical education and sport documents in middle school-first cycle of education in Italy. Journal of Physical Education and Sport, 2012; 12(2): 157-163.

8. Raiola G. Motor learning and teaching method. Journal of Physical Education and Sport, 2017; 17: 2239-2243. https://doi.org/10.7752/jpes.2017.s5236

9. Barnett LM, Telford RM, Strugnell C, Rudd J, Olive LS, Telford RD. Impact of cultural background on fundamental movement skill and its correlates. Journal of Sports Sciences, 2019; 37(5), 492-499. https://doi.org/10.1080/02640414.2018.1508399

10. Marchenko S, Bezpalko D. Control and Assessment of 7-Year-Old Boys' Coordination Abilities at the Initial Training Stage in Kyokushin Karate. Journal of Learning Theory and Methodology, 2020; 1(2): 82-88. https://doi.org/10.17309/j1tm.2020.2.06

11. Thienes G, Glage D. Influence of motor coordination on learning a gross motor task. German Journal of Exercise and Sport Research, 2020; 50(1): 60-70. https://doi.org/10.1007/s12662-019-00626-w

12.Ivashchenko O, Berezhna H, Cieślicka M. Motor Skills in the Structure of Physical Fitness of 7-Year-Old Boys. Journal of Learning Theory and Methodology, 2020;1(1): 14-19. https://doi.org/10.17309/j1tm.2020.1.02

13. Marmeleira J, Folgado H, Martínez Guardado I, Batalha N. Grading in Portuguese secondary school physical education: Assessment parameters, gender differences and associations with academic achievement. Physical Education and Sport Pedagogy, 2020; 25(2): 119-136. https://doi.org/10.1080/17408989.2019.1692807

14. Hiley MJ, Schmid N, Yeadon MR. How do technique and coordination change during learning of a wholebody task: Application to the upstart in gymnastics. Journal of Sports Sciences, 2019; 37(20): 2374-2380. https://doi.org/10.1080/02640414.2019.1634413

15. Meier C, Fett J, Gröben B. The influence of analogy instruction and motion rule instruction on the learning process of junior tennis players: Qualitative assessment of serve performance. German Journal of Exercise and Sport Research, 2019; 49(3): 291-303. https://doi.org/10.1007/s12662-019-00589-y

16.North JS, Bezodis NE, Murphy CP, Runswick OR, Pocock $\mathrm{C}$, Roca A. The effect of consistent and varied followthrough practice schedules on learning a table tennis backhand. Journal of Sports Sciences, 2019; 37(6): 613-620. https://doi.org/10.1080/02640414.2018.1522683

17.Aiken CA, Post PG, Hout MC, Fairbrother JT. Self-controlled amount and pacing of practice facilitate learning of a sequential timing task. Journal of Sports Sciences, 2020; 38(4): 405-415. https://doi.org/10.1080/02640414.2019.1704498

18.Di Palma D, Cusano P. Evaluation techniques and strategies applied to experimental educational projects for motor learning through the practice of karate. Sport Science, 2020; 14: $60-66$

19.D'isanto T. Competencies and skills in exercise and sport sciences program by online education. Sport Science, 2020; 13(1): 95-98.
20.Bolger LA, Bolger LE, O’Neill C, Coughlan E, Lacey S, O'Brien W, Burns C. Fundamental MovementSkillProficiency and Health Among a Cohort of Irish Primary School Children. Research Quarterly for Exerciseand Sport, 2019;90(1):24-35. https://doi.org/10.1080/02701367.2018.1563271

21.Bolger LE, Bolger LA, O'Neill C, Coughlan E, O'Brien W, Lacey $\mathrm{S}$, et al. Global levels of fundamental motor skills in children: A systematic review. Journal of Sports Sciences, 2021;39:717-53. https://doi.org/10.1080/02640414.2020.1841405

22.Freitas E, Saimpont A, Blache Y, Debarnot U. Acquisition and consolidation of sequential footstep movements with physical and motor imagery practice. Scandinavian Journal of Medicine and Science in Sports, 2020; 30(12): 2477-2484. https://doi.org/10.1111/sms.13799

23.Elghoul Y, Bahri F, Souissi MA, Chaâri N, Souissi N, Frikha M. Difficulty-manipulation-based learning effects on throwing performances and achievement goals in young boys. Acta Gymnica, 2021; 51. https://doi.org/10.5507/AG.2021.005

24.González-Víllora S, Evangelio C, Sierra-Díaz J, FernándezRío J. Hybridizing pedagogical models: A systematic review. EuropeanPhysicalEducationReview,2019;25(4):1056-1074. https://doi.org/10.1177/1356336X18797363

25.Krause L, FarrowD, PinderR, BuszardT, Kovalchik, S, ReidM. Enhancing skill transfer in tennis using representative learning design. Journal of Sports Sciences, 2019; 37(22): 2560-2568. https://doi.org/10.1080/02640414.2019.1647739

26.Chan CHS, Ha ASC, Ng JYY, Lubans, DR. Associations between fundamental movement skill competence, physical activity and psycho-social determinants in Hong Kong Chinese children. Journal of Sports Sciences, 2019; 37(2): 229-236. https://doi.org/10.1080/02640414.2018.1490055

27.Chang SH, Ward P, Goodway JD. The effect of a content knowledge teacher professional workshop on enacted pedagogical content knowledge and student learning in a throwing unit. Physical Education and Sport Pedagogy, 2020; 25(5): 493-508. https://doi.org/10.1080/17408989.2020.1743252

28. Marchenko S, Taranenko O. Managing the Effectiveness of Teaching Boys Aged 10 Mawashi-Geri (Roundhouse Kick) Technique in Kyokushin Karate. Teoriâ ta Metodika Fìičnogo Vihovannâ, 2020; 20(4): 262-268. https://doi.org/10.17309/tmfv.2020.4.10

29.Khudolii OM, Ivashchenko OV, Iermakov SS, Rumba OG. Computer simulation of Junior gymnasts' training process. Science of Gymnastics Journal, 2016; 8(3): 215-228.

30.LopatievA, Ivashchenko O, Khudolii O, Pjanylo Y, Chernenko $\mathrm{S}$, Yermakova T. Systemic approach and mathematical modeling in physical education and sports. Journal of Physical Education and Sport, 2017; 17(s1): 146-155. https://doi.org/10.7752/jpes.2017.s1023

31.Khudolii O. Research Program: Modeling of Young Gymnasts' Training Process. Teoriâ ta Metodika Fizičnogo Vihovannâ, 2019; 19(4): 168-178. https://doi.org/10.17309/tmfv.2019.4.02 


\section{Information about the authors:}

Olha Ivashchenko; (Corresponding Author); https://orcid.org/0000-0002-2708-5636; ivashchenko@hnpu.edu.ua; Department of Theory and Methodology of Physical Education, H.S. Skovoroda Kharkiv National Pedagogical University; Kharkiv, Ukraine.

Sergii lermakov; https://orcid.org/0000-0002-5039-4517; sportart@gmail.com; Department of Sports, Gdansk University of Physical Education and Sport; Gdansk, Poland.

Oleg Khudolii; https://orcid.org/0000-0002-5605-9939; khudoli@hnpu.edu.ua; Department of Theory and Methodology of Physical Education, H. S. Skovoroda Kharkiv National Pedagogical University; Kharkiv, Ukraine.

Cite this article as:

Ivashchenko O, lermakov S, Khudolii O. Modeling: ratio between means of teaching and motor training in junior school physical education classes. Pedagogy of Physical Culture and Sports, 2021;25(3):194-201.

https://doi.org/10.15561/26649837.2021.0308

This is an Open Access article distributed under the terms of the Creative Commons Attribution License, which permits unrestricted use, distribution, and reproduction in any medium, provided the original work is properly cited (http://creativecommons.org/licenses/by/4.0/deed.en).

Received: 10.05.2020

Accepted: 25.06.2021; Published: 30.06.2021 